\title{
WAYS OF FORMING THE TECHNIQUE OF SOUND PRODUCTION IN THE INTERPRETATION OF MULTI-STYLE PIANO MUSIC
}

\section{Yulia Tarchynska ${ }^{1}$}

DOI: https://doi.org/10.30525/978-9934-26-001-8-1-9

Abstract. The article discusses the ways of the optimal formation of sound production techniques in the interpretation of multi-style piano music. The research methodology is based on the use of the historical method to highlight the evolution of methodological approaches to the formation of piano performing technique; analytical - to study the problem in scientific research in psychology, psychophysiology, musical pedagogy, piano performance; musicological method of analysis of piano styles; method of generalizing the piano performing experience of leading artists to substantiate the peculiarities of performing intonation of multi-style piano music. The purpose of this study is to identify the integral direction of improving the process of the formation of instrumental and performing technique, to concretize the sound forms of the embodiment of key pianistic skills, and to outline their typical motor characteristics.

For the purpose of the study, methodological approaches to the formation of performing technique in the history of piano pedagogy are analyzed. The evolution of views on the technical development of the performer in different piano schools appears as a transition from empirical methods to scientifically grounded ones, as a change in the subject of the direction of the pianist's consciousness: identification of the most advanced forms of playing techniques, maximum attention to the sound result with the intuitive establishment of auditory-motor connection, conscious processing of auditory-motor coordination.

The conditions for the optimal development of piano playing technique are considered, taking into account scientific achievements in the field of physiology, psychophysiology, and musical pedagogy. The circle of those

\footnotetext{
${ }^{1}$ Candidate of Pedagogy,

Associate Professor of the Department of Musical Instruments Playing, Institute of Arts of the Rivne State Humanitarian University, Ukraine
} 
skills of the pianist is determined, the acquisition of which optimizes the technical development of the performer: the skills of style-like sound production and sound science, which make up the technique of stylelike sound formation. The content of the process of conscious mastering of interdependent and mutually conditioned components of such playing techniques is specified: generalized understanding of the common factors of the musical and linguistic environment of a certain piano style; creation of vivid sound-like performances based on emotional and intellectual comprehension of musical compositions, coordination of auditory-motor representations of such «mobile» expressive means as articulation, dynamics, agogics and timbre; improvement of motor skills from the point of view of physical convenience with the help of associations with previously acquired relevant performance experience, as well as life motor experience of economical expedient use of motor activity.

The main stylistic features of sound production techniques in the interpretation of the piano heritage of Ludwig van Beethoven, Fryderyk Chopin, Serhiy Prokofiev are characterized on the basis of an analysis of their aesthetic ideals, «stable» and «mobile» expressive means of the composers' music, and the performing styles of the artists themselves. The examples of effective mastering by specific ways of combining tones that are appropriate in the style of composers are given. The described playing techniques are primarily a reference point in the art of sound production, a generalization of the rich scale of the pianistic initial touch. In practice, certain changes, combinations of techniques and movements can and do occur. In order to render the specific content of a piece of music, it is often necessary to deviate from the «textbook» way of playing with «exemplary» movements.

At the same time, mastering the relationship and interdependence of stylistically conditioned sound tasks and expedient motor skills will make it possible to variably apply the playing techniques mastered in the embodiment of many nuances of the soundest images of highly artistic pieces of piano music.

\section{Introduction}

The art of playing a musical instrument, in particular the piano, presupposes possession of a complex set of knowledge, skills, and abilities of the performer. The value of interpreting a piece of music depends on 
the level of development of emotional sensitivity to the artistic and aesthetic properties of piano opuses, the amount of theoretical and practical knowledge of musical languages, genres and styles of piano music, as well as on the ability to solve various performing tasks: sound production, expressive intonation, mastery of various types of techniques, achievement of virtuoso effects according to artistic intentions. Therefore, the process of educating the performer is quite long. As a rule, years pass from the initial acquaintance with the instrument and to the mastering of the programs of the highest performing complexity. The whole life of the master is devoted to the improvement of performing skills.

Therefore, the issue of effective performing training, understanding in this regard the performing heritage and pedagogical practice of artists of the past and present have aroused and constantly arouse the interest of prominent musicians and famous scientists (O. Alekseev, D. Blahoy, L. Barenboim, T. Birmak, F. Buzoni, D. Herasymovych, J. Hoffman, N. Huralnyk, M. Davydov, K. Ihumnov, O. Kirchanova, E. Lieberman, A. Malinkovska, A. Maslovsky, I. Marchenko, K. Martinsen, T. Mariupolska, J. Milstein, B. Milich, N. Mozgalyova, H. Neuhaus, V. Petrushyn, S. Savshinsky, H. Tsypin, M. Feigin, S. Feinberg, V. Shulgina, V. Shulpyakov, O. Shcholokova, B. Yavorsky etc.).

Over the past decades, various methodological aspects of piano teaching have been considered in scientific researches. H. Saik [32] suggests to optimize the process of formation of performing skills on the basis of effective development of emotional and aesthetic experience of music. Wang Bing [9] summarizes the existing trends in the formation of performing techniques in order to identify the factors of improving this process (the researcher also submits a series of exercises based on the pianist's rotational, tactile and figurative sensations that perform an artistic task). N. Mozgalyova [29] focuses on the phenomenon of timbre, prompting the scientist to introduce the appropriate principle in piano training. Lu Chen [11] reveals the specifics of the effective formation of the skills of musical-performing articulation, provided that the primary activation of perceptual and reflexive activity, and then - the activation of productive and technological, performing actions are observed.

At the same time, it will be relevant to emphasize the fundamentally important general direction of optimizing artistic and technical development 
in the instrumental class. In this regard, it is advisable to determine the range of those skills of the pianist, the acquisition of which will optimize the process of forming the technique of playing the piano. It is also important to clarify the technology of conscious development of auditorymotor coordination. These questions will be considered on the example of the peculiarities of performing nuances in the interpretation of piano styles that determine the development of pianism.

In the study, we used: historical method to highlight the evolution of methodological approaches to the formation of piano performing technique; analytical - to study the problem in scientific research in psychology, psychophysiology, musical pedagogy, piano performance; musicological method of analysis of piano styles; method of generalizing the piano performing experience of leading artists to substantiate the peculiarities of performing intonation of multi-style piano music.

The scientific novelty of this study lies in the identification of the main factor in the improvement of the instrumental-performing technique: rational development of the technique of style-like sound formation, concretization of the sound forms of embodiment of the indicated pianistic skills, outlining their typical motor characteristics.

\section{Problem of technical development in the history of piano pedagogy}

The wide spread of the piano, and then the formation of piano pedagogy, fell on the late XVIII - early XIX centuries and coincided with the flourishing of classicism in art. Piano-performing author's schools developed the experience of organ-clavier pedagogy, adapting it to new requirements.

The capabilities of the new instrument of the fingerboard-string group the piano, the new requirements of the «brilliant» style prevailing at that time on the concert stage significantly deepened one of the features of professional training in the era of harpsichord art - the priority of virtuosity over content. The task of the performer of «diamond» pieces, «mezzo staccato» passages, greater resistance of piano keys in comparison with the old clavier led to the search for new methods of playing, the development of which was carried out by representatives of the traditional pianopedagogical direction (M. Clementi, L. Adam, J. Hummel, F. Kalkbrenner, K. Cherny, S. Thalberg, J. Field etc.). 
In this school, the essence of improving performance skills was reduced to the development of not only the dexterity and accuracy, but also the strength and independence of «isolated» fingers. Thus, I. Hummel proposed to use a series of exercises in training with a motionless hand to develop the strength and independence of the fingers. Such views, however, concerned only the «learning method» and differed «from the views on the use of the hand during the play» [6, p. 229]. In particular, I. Hummel demanded subtlety of sensations in the fingertips, opposing the spirituality of the play to mechanical perfection.

The inconsistency of this position is explained by the beliefs of those days about the localization of motor training in the peripheral musculoskeletal system. This gave rise to a tendency in the piano pedagogy of the era of classicism to differentiate in the formation of the performer's technique and artistic thinking. «The «old» piano school re-emphasized the attention of pianist teachers in the education of a musician-interpreter to the training of a virtuoso [22, p. 22].

Gradually, in piano pedagogy new ways of overcoming the indicated disadvantages of the mechanistic approach emerged. The innovative pedagogy of outstanding composers, who were significantly ahead of their time in the development of piano-methodical thought, played an important role in this.

In particular, L. Beethoven considered technique to be an artistic function of performance, and proposed using weight and integral hand movements in the play. R. Schumann, F. Chopin, F. Liszt also approved the performer as an interpreter of the music. The main principles of their progressive pedagogy were: development of spiritual qualities and intelligence, intense mental activity; general aesthetic development; meaningfulness, spirituality of performance, as the main goal, and technique, as means serving it; concentration of auditory attention, development of inner hearing; use of new technical and fingering techniques (great technique, freedom of the apparatus, participation of the body, use of the natural capabilities of each finger, bold, individually selected finger notation) [22, p. 26].

However, the new performance requirements of romantic piano literature, the complex technical challenges of this style became a serious problem for many pianists brought up by traditional methods. The reason for the failure to overcome complex texture problems in the works of 
R. Schumann, F. Chopin, F. Liszt was seen in the lack of conscientiousness in learning activity. As a result, the increased training of virtuoso performers of the «old» school led to tragic consequences: occupational diseases of the hands began to acquire a massive character until the end of the 19th century.

The reaction of piano pedagogy to such negative processes was the emergence in the second half of the 19th century of a new direction, the goal of which was to oppose the empirical methods of the traditional school to new, scientifically based ones. Music teachers and theorists of pianism (L. Deppé, R. Breithaupt, F. Steinhausen, and others), in search of ways to rationalize the work of the performer, turn to the natural sciences, primarily to human anatomy and physiology. This appeal is dictated by the desire to find perfect forms of playing techniques, which would facilitate the process of performance, and, as a result, remove the problem of hours of training.

Anatomo-physiologists draw the attention of pianists to the naturalness of the interaction of all parts of the hand in the performing process, to the expediency of free pianistic movements. Considering performing actions from the point of view of economical use of muscular energy, R. Breithaupt introduces into the methodology the idea of «weight» play: the use of the natural weight of large arm muscles to help fingers.

The theorists of the new trend for the first time in piano pedagogy drew attention to the role of consciousness in mastering technical skill. The anatomophysiologists opposed the intensive physical training with the analytical work of the pianist. But in this school the functions of the performer's consciousness were considered, in fact, outside the figurative-semantic and stylistic context of musical compositions. The pianist's mental work was primarily aimed at defining and developing physiologically expedient motor techniques. The connection between the nature of the sound task and the form of movement was definitely recognized, but the desire to establish «standard» recipes for the rational form of the corresponding performing actions indicates an underestimation by anatomo-physiologists of the decisive influence of musical and auditory representations on the technique of playing. This understanding of the pianistic work led the supporters of this trend to the absolute priority given to the «flying-sweeping» and «rotating» forms of movements and underestimation of the role of finger technique.

The representatives of the psychotechnical direction, which was formed at the beginning of the twentieth century, sought to optimize the process 
of mastering performing skills, directing the attention of pianists to the embodiment of vivid musical and auditory performances. «Make sure that the imaginary sound picture becomes clear, the fingers must and will obey it," recommended the Polish pianist, renowned interpreter of Chopin's music I. Hoffman [17, p. 58]. The founders of the new school and the expressers of its ideas were the outstanding teachers and masters of pianism F. Busoni, V. Bardas, M. Varro, I. Hoffmann, K. Leimer, K. Martinsen and others.

The primary task of the formation of a performer in this school is the upbringing of his/her musical and figurative thinking, the development of musical abilities, emotionality. The main attention is directed to the deep comprehension and delivery of the idea of the composition. At the same time, the expediency of playing techniques is determined by their ability to acquire the desired sound result.

The essence of piano lessons should be reduced to the rationalization of auditory-motor representations: "The point is to harmonize the representations (sound image) with the actual reproduction (real sound). This harmonization must be continued until with each movement, which more or less closer to the desired goal, a well-guessed muscle sensation is formed, and until a strong connection is formed between the sound image and the muscle sensation. In the future, one sound image is enough to bring to life the corresponding muscle sensation» [5, p. 53]. Such thoughts of psychotechnicians represent their belief in a direct connection between the auditory sphere and the performer's motor skills, in the fact that the process of inception of the pianist's motor techniques occurs in the best way subconsciously, when the sound image is embodied.

The considered methodological principles influenced the development of the Ukrainian pianistic school, which inherited the foundations of the European ones: Viennese (T. Leshetytsky - V. Puhalsky), Leipzig (L. Brasssen - V. Safonov - H. Beklemyshev), «Slavic» (F. Chopin F. Blumenfeld).

The main distinguishing features of the methodological developments of Ukrainian piano teachers in this aspect are: understanding of professional performance as a result of deep penetration into the essence of the musical image, cultivating a harmonious combination of intellectual comprehension and emotional perception of a piece of music, condemnation of superficially virtuoso performance, condemnation of the mechanical training, an 
appeal to constant auditory control over the use of a complex of means of performing intonation; interpretation of the pianist's technique as a means of revealing a musical and artistic conception, connection of technical perfection with a variety of sound colors, sophistication of nuance, artistic perfection of playing; an observance of the basic motor principles: freedom and expediency of movements, holistic use of all motor capabilities of the pianistic apparatus with perfect finger play [39].

\section{Sound production corresponding to the style is the basis of instrumental performance technique}

With the assertion of performing as an independent sphere of creativity in musical culture, the concept of interpretation emerges (lat. - lectio, interpretatione). The composer's clear presentation of the sound image of the musical composition, in fact, is already for him/her the realization of his/ her own idea. The performer's skill combines the inner life of musical and auditory representations and their external form of sound: the clarification of the sound image in the interpreter's professional activity is supplemented by the search for appropriate performing means of its reproduction.

Musical pedagogy of the second half of the twentieth century was enriched with the meaningful theoretical and methodological provisions on various aspects of the performing process. Developing and summarizing the best achievements of the piano schools, experts in the field of the theory of pianism and methods of piano teaching - O. Alekseev [1], L. Barenboim [6], T. Berkman [7], H. Kogan [21], N. Lyubomudrova [23], A. Malinkovska [25], V. Makarov [24], B. Milich [26], S. Savshinsky [34], E. Timakin [41], S. Feinberg [13], H. Tsypin [42] - gave the utmost importance to work on sound and auditory introspection. The sound formation culture of the pianist became the central problem of methodological thought. It was viewed in the general context of the musician's performing skills.

The activity of an instrumentalist covers almost all forms of musical and mental actions. In the performance, to one degree or another, such varieties of musical creativity are represented as the perception of music, music-making, the composer's creativity itself, because it combines cognitive, transformative, value-oriented and communicative types of human activity [33].

At the initial stage of mastering the composition, the primary comprehension of the artistic image takes place, based on «a person's 
ability to sensually perceive the expressive meaning of musical intonation, to emotionally respond to it» [43, p. 136]. The process of reproduction of musical and sound images requires a deep penetration into the expressive and semantic essence of the composer's intention.

The musician's interpretation of the musical text begins with an understanding of the logic of the connection between the structure and the figurative and semantic meaning of the musical structure of the composition. In this aspect of performing comprehension, first of all, the "stable" properties of the musical form are considered and creatively "guessed", according to V. Moskalenko [28]. That means all that is not corrected by the interpreter (for example, the pitch organization of the piece of music, the logical functions of voices in the general musical structure, register, type of texture, etc.) The intellectual comprehension of a musical composition is also largely facilitated by associative representations that arise from operating with knowledge of the composer's style, the history of writing the composition, important facts from the musician's biography, and the like.

The work of the interpreter takes place both at the level of consciousness and in the sphere of actual performance. The embodiment of the imaginary artistic picture of the composition, the materialization of its ideal model in real sounding occurs through the search and use of appropriate performing means adequate to the forms of intonation expressiveness conditioned in the musical composition. These means are of great expressive and formmaking value. Corresponding to the «mobile» properties of the musical form (articulation, dynamics, agogics, etc.), they ensure the adequacy of the interpretation of the composer's idea and a certain freedom of its performing interpretation at the same time.

The playing techniques formed in the process of performing composition are due to the multicomponent structure of sound image representations [37] - melodic, timbre-dynamic, articulatory, metro-rhythmic and formcreating. Therefore, any technique of an interpreter has a sound-creative characteristic. In this regard, the performer's auditory-motor coordination is considered in the interconnection and interdependence of all its components. Hence - modern instrumental pedagogy clearly emphasizes the need to achieve the unity of the artistic and technical development of the performer.

Thanks to significant studies of the principles of human motor activity (P. Anokhin [3], M. Bernstein [8], V. Zinchenko [44], L. Chkhaidze [12] 
and others), the unity of artistic and technical instrumental and performing development is understood as a harmonious combination of musical and artistic education of an instrumentalist with the formation of his «purposeful» (in sound result) and «expedient» (due to the task of physical convenience) playing technique.

Any purposeful activity based on the conclusion of the outstanding researcher of the brain of the XX century M. Bernstein [8] is regulated by an internal (imaginary) model of a goal or an image of the supposed future. The process of this regulation is ensured by the transmission through the senses and the processing of information about the correspondence of their movements to the goal. The received signals (sensory) about the progress of the action are compared with its image and assigned to (or inhibited by) motor impulses as corresponding (not corresponding) to the internal model of the goal. Thanks to such a closed circle of control, a sensorimotor system gradually develops, in which sensory corrections for various elements of motor activity are precisely coordinated; the integral way of activity is also specified.

In the performing arts, musical and auditory performances and the corresponding motor skills are coordinated in an integral type of activity. The main sensorimotor correction in the control of performing actions is, as noted above, the qualitative characteristics of the obtained sound result.

Considering the regularities of the relationship between the mental and physical spheres in the creative work of a performer from the standpoint of scientific conclusions about the activity of the central nervous system in the construction of movements, A. Shulpyakov [35] dwells in detail on the role of consciousness in the process of formation of playing techniques. $\mathrm{He}$ emphasizes that in the course of musical performance search, auditory and motor components interact, as a rule, on an irrational basis. High levels of the central nervous system, coordinating the motor process with the help of auditory sensations, affect its character, while showing indifference to the motor composition of playing techniques. The subordinate level of the central nervous system without the intervention of consciousness is not able to create an optimal base for complex performing movements. Thus, being formed as a result of the interaction of auditory representations with the individual playing apparatus of the instrumentalist, the techniques of playing can take on a form that will not serve the musical goals set in the 
best way (from the point of view of physical convenience). Therefore, performing techniques require additional conscious adjustment to establish the optimal correspondence of the motor means to the artistic goal.

The author proposes to activate the process of combining musical and auditory representations with purposeful (aimed at a musical result) and expedient (physically convenient) types of performing movements with the help of associative application of the previously acquired motor experience in accelerated effective mastering of playing techniques. The search for common aspects of new and previously mastered performing movements (life motor experience as a whole can be used) should be based on taking into account the similarity of the types of sensory corrections, and not the external form of actions, which will definitely acquire individual traits for each performer.

In the instrumental class, it is important to observe the conditions for optimal mastering by methods of performing intonation. However, it is equally important to create a good basis for the performing development of an instrumentalist who is able to independently solve problems of expressive intonation speech.

The researchers of movement problems note the suitability of the formed sensorimotor image in the regulation of new actions. It can more effectively perform the role of a regulator for one or another class of movements. The scope of this class is usually limited: the formed image may not be suitable for all cases of life, but it is constructed as invariant to a certain set of actions performed [16, p. 123].

Methods for combining tones on the piano are generalized to typological scale of strokes, volume dynamics, variable tempo, various ways of using the pedal. The sphere of these means of expressiveness in musicology is referred to as stylistic features along with other leading elements of the structure of the musical style - musical thematic invention, musical language, musical form. Therefore, various methods of sound production relate to a certain musical and stylistic environment.

In all the variety of piano-performing technique, the essential characteristics of the technique of stylistically corresponding sound formation are constantly shown (of course, variably). In this regard, the conscious mastery of the interdependent and mutually conditioned components of such playing techniques will create conditions for effective 
performance training in the piano class. In the consciously developed skills of auditory-motor coordination, the artistic image, the corresponding sound image, and the appropriate motor techniques must be comprehended. The technique of sound creation and sound production should be additionally monitored exclusively as an awareness of the nature of internal sensations accompanying the movements.

When forming the style of the corresponding technique of sound creation, it is not necessary to study the opuses of all the existing composing schools. With an increase in the degree of subordination of style elements, their versatility increases. Therefore, the relative secondary importance of the methods of piano-performing intonation enhances their invariant significance for the performing technique. In addition, despite the affinity of the phonic ideas of the metatext of piano music, it is possible to master the typical ways of the style of the corresponding technique of sound production in the study of the piano styles that determine the development of pianism.

\section{Peculiarities of sound production in the piano style of $L$. Beethoven}

One of these styles in the late 18th and early 19th centuries is the piano heritage of the German composer Ludwig van Beethoven. The master's creative work establishes the trend of the so-called «heroic» pianism.

The chamber transparent sound of classicist works of the 18th century is replaced by the «symphonism» of Beethoven's piano opuses. Permeating the piano musical structure with symphony, he seeks sonorities that can reproduce the color of orchestral timbres. Beethoven maximally expands the sound spectrum of this instrument, he actually «transcends the boundaries of pianism of the early XIX century» [40, p. 9]. Calling his latest sonatas «compositions for a hammerklavier", the composer emphasized their modern pianistic expressiveness, the difference between his music for the grand piano and the modest classical piano style, which is largely associated with the art of the harpsichord.

The boldness of innovation in Beethoven's musical language is due to the nature of the ideas of his compositions, which were first heard in the art of secular music-making with such a philosophical depth and scale. The predominance of massive loudness in the composer's piano heritage is associated with the dominance in the composer's music of high tension of 
feelings, a huge charge of energy, powerful dynamism. In this fundamental aspect of his opuses, there is a special theme of Beethoven's creative work the theme of the titanic struggle of the hero. To a greater or lesser extent, it permeates all his compositions, regardless of the dominance of classical or romantic coloring in them.

Beethoven quite clearly defines the character of performing intonation in his musical text. In particular, the composer makes remarques in the field of articulation with sufficient professional concreteness and thoroughness, like the style of orchestral writing with its inherent accuracy and systematic recording of strokes.

Most often in his piano compositions such a method of pianistic pronunciation as legato is used. If in the initial opuses non legato remained the natural touch for the composer, then over time Beethoven's pianism «puts forward legato as the main articulatory feature» [36, p. 65]. An increase in the coherence of the playing is due to the smoothness of the melodic lines of the composer's later sonatas, the presence of a large number of dynamic passages that show the artistic-figurative essence of the composition, but not distinguished by an exclusively virtuoso orientation, the intense loudness of Beethoven's pianos with the melody of their tone. However, it should be noted that the ideal of melodic piano playing at the turn of the XVIII-XIX centuries had peculiar features: such a legato was closer to smooth speech than to "cantilence" in the spirit of Italian bel canto.

When performing this type of legato, all parts of the hand must be involved. Sensitive fingertips press keys at close distance to them. Release keys - not with the help of a purposeful active autonomous movement, but by voluntary actions arising from the «transfer» of the weight of the hand from one finger to the other. The contour of elastic movements of the wrist and the entire performing apparatus, depending on the highest or lowest position of the hand, which naturally occurs when playing with different fingers, will be determined by patterns-configurations of textured sequences and, accordingly, selected fingering.

Melismas of Beethoven's piano music, broken chords, light passages of a virtuoso character require a specific legato touch. An emphasized legato performance is achieved through increased finger action and a learned sense of freedom in hand and wrist movement. It is more convenient to get acquainted with this type of connection of tones in an elastic and simultaneous 
movement of alternating «press-and-release» tones of a second. One finger by actively pressing a key, seems to "push» the other from the adjacent one. As a result, a feeling of inertia appears in the movements of the fingers, and freedom in the hand and forearm.

The staccato stroke is also quite common in Beethoven's piano texture. Within such means of expressiveness, various playing techniques are used. In vivace and allegro tempo, mainly at high volume, it is appropriate to use the technique of playing «from the elbow». In a transparent texture, where a fast-paced staccato sound is combined with a low volume, it is advisable to make performing movements from the wrist joint. In any case, it is important to check the presence of inertia in vibrations.

It is much easier to achieve freedom in hand movements when reproducing the coloring of the abrupt sound of various orchestral instruments with the help of light finger strokes, after which their tips almost do not move away from the keys.

A detailed consideration of the methods in the corresponding style of the technique of sound production contains the author's textbook: «Formation of rational techniques for playing the piano» [40].

The symphonization of the piano sound appeared in many expressive meanings of Beethoven's dynamics. Its typical feature is loudness contrast. In this regard, A. Aronov [4] defined Beethoven's dynamics as "dinamica subita". The researcher gave her characteristic contrasting techniques: juxtaposition of excellent loudness levels, accent, $\mathrm{p}<\mathrm{p}$ nuance, that is, crescendo, which suddenly turns into piano at the moment of climax.

The orchestral nature of the composer's musical thought was also in the expansion of the range of piano loudness. The limits of this range are from ppp to ff.

The symphonization of the piano sound becomes especially noticeable when Beethoven requires the pianist to increase the loudness of one note or chord. It is no doubt that observance of this nuance is possible only in the auditory imagination, and the confirmation of its performance will be the sound of the next musical material, which will be perceived as the completion of the crescendo of the previous one. The crescendo and diminuendo, which Beethoven uses to build a large phrase, imitate the orchestral effect of long symphonic rises and long decays: Sonata op. 106, II ch., vol. 49-54. 
The formation of the pianist's readiness skill, characteristic of the interpretation of Beethoven's music, for rapid, almost instantaneous changes in the playing technique, especially in the field of dynamics, should be preceded by the achievement of a high-quality performance of any touch of equal loudness. Next - mastering the skills of playing long uniform dynamic rises and falls (this task is rightly considered quite difficult in sound production). The change in loudness should be associated primarily with the feeling of the heterogeneity of the weight of the pianist playing apparatus, which comes from larger or smaller sources of hand power.

The textual remarks in Beethoven's compositions help to correctly reproduce the peculiarities of tempo-rhythmic nuances and pedalization. The latter is indicated by the composer in voiced (f) and sufficiently voiced (ff) parts. In addition to increasing the loudness, it also provides for the creation of a contrast of sound coloring between adjacent chapters.

The acquaintance with the outstanding musician's own playing manner helps to understand the basic requirement of the technique of sound production in the Beethoven style of pianism. It, as noted by researchers [2, p. 124-127; 14 , p. 174-176; 20, p. 257-260], differed from art of the modern Viennese pianists. There was no gallant stiffness or filigree in Beethoven's playing. It was distinguished by simplicity, deep and strong feeling. The composer opposed his performing style to the traditional for brilliant pianism - «perle». For him, the piano turned into a small orchestra, some passages gave the impression of powerful streams, avalanches of sonority.

Beethoven did not follow the prevailing doctrine of the need to play with his very fingers. In organizing the pianist playing apparatus, he was far ahead of his era. Some of Beethoven's exercises, recorded in his musical notation and sketch books, cannot be performed either with a tightly clutched or too relaxed hand. Beethoven attached great importance to the use of its weight and strength, to the integral movements of the pianist playing apparatus.

Due to the "specific gravity" of Beethoven's sound, which L. Gakkel compared with "sculptural material" [15, p. 226], the performer's hands and fingers often have to withstand the loads coming from the large links of the playing apparatus. Therefore, their position during the playing should be elastic, composed and at the same time flexible.

Such an organization of the pianist playing apparatus requires, first of all, the formation of expedient ideas about finger work. It should be 
based on the most natural movements of the fingers. At the heart of these movements, as noted by V. Petrushin [31, p. 53, 54], - the usual grasping reflex. A characteristic feature of this movement is the movement of the fingertips inward, into the palm, which makes the movements economical and sensitive at the same time. Such economy is provided by the minimum amplitude of finger movements, and sensitivity - by the similarity in the nature of the actions of the process of touching an unfamiliar object, when information about it is acquired on the basis of tactile sensations. While groping, the greatest level of comprehension of both the object and the motor sense is achieved.

In addition, with the help of this playing technique, synesthetic connections are easily formed, in which sound and tactile sensations merge into a single whole. Soft smooth touch at low volume or energetic strong touch at high volume - this technique equally perceptibly achieves any sound shades. And the movement of the finger into the palm or «towards oneself» will not lead to excessive tension of the hand and arm, when the support of the finger on the key will be perceived as «touched» hanging of the free hand on it. That is, when muscle flexion, which is localized in the fingers and hand, will be balanced by the desire to release the muscles of the shoulder and part of the forearm.

\section{Peculiarities of sound production in the piano style of $\mathbf{F}$. Chopin}

The creative work of the Polish artist Fryderyk Chopin opened a new page in pianism, even giving birth to a special performing specialization "Chopinists". The composer and pianist has created a unique style, devoid of tension, light and soft in sound, which is marked by great melodic smoothness, grace and aristocracy.

The main sound feature of his music is the melodiousness of the piano performance. The graceful lyricism of Chopin's sonorics, its special tenderness, the muted colors actually open up practically unlimited possibilities for expressive performing intonation for the pianist, given the richness of nuances in the melodious sound production.

The fundamental difficulty in interpreting the composer's opuses is the polysemy of their figurative content, due to the deep psychological nature of Chopin's music. Almost no single pianist can cover all the components of its content, as noted by N. Kashkadamova [19, p. 216]. 
The composer skillfully conveyed in his compositions how different, sometimes contradictory tendencies and impulses of a man of the XIX century can merge into one whole. Hence - the breadth of various, also opposite combinations in Chopin's compositions: poetry, grace, gentleness and courage, heroism, dramatic greatness; elegance, virtuosity, charm and brilliance - and simplicity, complete sincerity, immediacy, clarity; pity and pain, sufferings, tragic pathos - and at the same time restraint, strict sense of proportion, exacting taste.

The composer's melodic style was influenced by Polish musical folklore. Although Chopin almost did not quote folk melodies in his opuses, the warmth, tenderness, and broad melodiousness native to folk art are brilliantly embodied in the artist's music. Chopin was also attracted by the melodiousness, elegance and flexibility of the melody of Italian opera.

Melodic richness is inherent not only in the upper voices in the compositions of the composer. It permeates their musical structure as a whole [27, p. 112-117]. Meanwhile, the polyphonization of texture, the wide use of the fingerboard volume and pedal never leads Chopin, unlike other romantic composers, to excessive density, oversaturation or heaviness of sound. His music is characterized by harmony and overwhelming transparency of presentation. In general, the expressive means of Chopin's compositions are addressed to a deep disclosure of the peculiar capabilities of the piano, which were not known in playing this fingerboard-string instrument until now.

The vocal and speech style of the composer's melody determined his broad approach to the problem of legato playing. Such remarques in his musical texts as poco legato, molto legato, ben legato, legatissimo testify to the extraordinary richness of the scale of coherent pronunciation. Legato was used by Chopin both to reproduce all manifestations of cantilence and in melodic passages, which were combined with the help of this type of articulation into one continuous line.

For the composer, the pedal plays an important role in maintaining and deepening the legato technique. At the same time, the very finger legato of Chopin's music is more diverse due to its rich emotional content. Various techniques of legato playing require an extraordinary expressiveness from the composer of the cantilena episodes. They use melodious types of touch, in which the movements of the fingers closely interact with the hand and 
the whole arm. Depending on the tasks of expressive intonation, a pressing technique or playing with a free hand weight is used.

The melodiousness of Chopin's piano sounding in the spirit of operatic art, the relief of its intonation development is emphasized by the wrist movements, which transfer different hand weights to the fingers. Actions associated with the sensation of losing her weight mainly fall on a weak beat of the bar, or at the end of the note, which ends the motive. At the same time, this pianistic «breathing» should not be too frequent, unjustified by musical sense [27, p. 40].

The richness of textured solutions in Chopin's passages requires extreme flexibility in coordinating the movements of the hand with the topography of the fingerboard and the individual structure of the fingers. The connection into one link of the sounds of different passages is performed by smooth turns of the hand into the next note by fingers of different lengths, the movements of which must be closely coordinated with the movements of the hand.

In ornamental passages, especially in such fast musical ornament as trill, the principle of using fingers in legato changes. The conjunct playing with pressing and tangible support in brilliant and sufficiently mobile episodes is replaced by a touch, in which pressing and support are relieved, and the movements of the fingers are activated.

Chopin's staccato of any form is not as common as legato. The composer used in his compositions, soft, smooth type of staccato touch. The staccato stroke gains various functions in his music. Quite often it performs a delimiting function when both staccato and legato are combined in different voices at the same time (Scherzo cis-moll, op. 39, vol. 77-82). The staccato strokes in Chopin's compositions also serve to emphasize dynamic peaks, important melodic sounds, rhythmic structures (Scherzo h-moll, op. 20, vol. 14-16; Waltz e-moll, vol. 15,16; Scherzo h-moll, op. 20, vol. 622-625).

Various types of touch are used in Chopin's staccato episodes, which are characterized by an active flexible push (involving the inertia of actions) of the fingers, hand, and in strong dynamics - the forearm.

Means of expressive intonation speech - dynamics, agogics, pedal serve to unite thematic links into a single melodic development. In Chopin, this development is often full of drama, intense emotions. Hence - a lot of climaxes in the composer's music. At the same time, the Polish artist strove 
to avoid dynamic extremes as much as possible, and more appreciated the inner logic of musical development. "Chopin, - as V. Gornostaeva noted, is a pure and deep romantic, but there is nothing external, ostentatious, theatrical in his romanticism... Cleared of all sorts of layers, external exaltation, Chopin's romanticism requires absolute sincerity from the performer" [18, p. 186]. The composer developed in his students the ability to master, in addition to the usual $\mathrm{f}$ and $\mathrm{p}$, all their possible transitional facets, a variety of colors within the piano, light but not soundless.

Objective requirements for expressiveness determine agogical nuances in the composer's works. It is appropriate even where there are no corresponding remarques: in a wide performance in the cantilena of distant intervals, lengthening of high notes, as well as dotted notes, a free recitative way of reading cantilena fragments, and the like. In general, free tempo is remembered as one of the most characteristic features of Chopin's music. The composer uses tempo rubato both in slow melodies and in live dance. Accelerations and decelerations are often accompanied by sound rises and falls. However, the composer's agogics is devoid of any exaggeration. His agogical designations reflect not sudden juxtapositions, but the process, the fluidity of musical development. A sign of exquisite taste in performance will be the interpretation of rubato as a consistency of deviation and stability.

Many of Chopin's artistic intentions are based on the desire to combine several dissimilar textured elements within one pedal to create a special filled harmonious humid phonic atmosphere. However, the excessive use of this means of expression was unacceptable for the composer. If, during the exact performance of long Chopin pedals on modern instruments, a falsity arises, it is worth finding that sound, that vertical and horizontal dynamics, which will save the playing of dissonant overtones. The composer himself always strived for harmony in the ratio of manual techniques and measures of pressing the pedal, he widely used half-pedals, quarter pedals and the like. The use of the pedal when the "incomplete" right is combined with the left will help to achieve sonic clarity while maintaining the necessary phonic completeness. The latter was used by Chopin not only to attenuate the loudness, but also to diversify the sound colors of the piano.

The piano coloring itself is a fundamental feature of the composer's thought of the Polish romantic. The «piano coloring «of this style also appeared in the aestheticization of hand movments in Chopin's compositions. 
And, of course, the composer retained and developed the best features of the classical piano school: graceful finger playing, real (and not just pedal) legato, etc. At the same time, Chopin's pianism is subtly adapted to the topography of the fingerboard. And its characteristic cantilence puts great demands on legato performance. Chopin's texture as a whole, with its inherent complex passages, polyphonic chords, changes in their close and wide placement, with a fairly frequent arpeggiated presentation, transitions from one register to another, also requires principles of pianistic embodiment different from the piano music of the composer's predecessors. In this regard, certain specific requirements are placed on the movements of the hand: extreme elasticity of the hand and flexible movements of the wrist.

In Chopin's compositions, great importance is attached to the individual difference in the attack of each finger. In fingering solutions, artistic intentions become of extremely high priority. The melodiousness and lively intonation in the new romantic technique of Chopin's compositions allows placing the first finger not only under the second or third, but also under the fourth and even under the fifth.

The sonic uniqueness of Chopin's music requires, in addition to the plastic interaction of all the links of the pianistic apparatus, special types of tone-touch, excluding the sharpness of sound, percussiveness in the touch of the hand to the fingerboard.

The perfection of the playing, the pianistic skill of the composer himself were inseparably connected with the ease of performance. S. Feinberg in this regard noted the typical character of Chopin's touch, intended for the duration of the piano sound. Its peculiarity lies in the fact that on this instrument rather loud sounds fade away faster than those which appear after smooth keystrokes [13, p. 228]. Thus, Chopin's sound colors, in which melody reigns, require characteristic plasticity in the touch of the fingers to the fingerboard.

During the performance of the finger movement - pressing the key in the music of the composer, it is necessary to find such a ratio of the swing with its weight and the weight of the pianistic apparatus as a whole, which at the moment of pressing the key will provide its pressing with the greatest plasticity.

Chopin's key "pressing" is mainly associated with their "stroking". It is performed in most cases of the «finger pad», the «support point» of 
which changes compared to the hitherto known playing. When the hand is concentrated, for example, the position of the arm rests on a naturally rounded finger, the support of which falls on the joints of the hand. In Chopin, the support of the fingers expands to the joint of the wrist, causing a distinct sensation of activation of the muscles of the palm, as well as the illusion of an elongated (up to the joint of the wrist) finger. And he presses the key not with the tip, but with a large part of his phalanx, which makes his finger sensitive and allows him to subtly differentiate the sound of the instrument.

The main thing in the keystroke itself is stroking, skewing of a direct finger strike. This technique performing can be supported by associating the trajectory of the finger movement before and at the moment of sound production with sliding along an imaginary arc, which starts from the inner side of the open fingerboard cover, then smooths the angle between it and the fingerboard and ends at the keys. In mastering the technique, an imaginary arc-«skating rink» line can be stretched along the key, unloading the arm by removing the elbow, as if preparing to pull it from the shoulder. Sliding the finger «towards you» is combined with its natural «immersion» in the fingerboard without exaggerating the weight of the hand.

\section{Peculiarities of sound production in the piano style of S. Prokofiev}

The artistic style of the Russian composer, pianist, conductor Serhiy Prokofiev (the composer was born and spent his childhood in the village of Sontseve, Dnipropetrovsk region, Ukraine) distinguished itself in the motley diversity of the cultural life of the XX century. He paved the way for an innovative direction in music both as a composer and as a performer. The artist's musical talent gave rise to a distinctive piano style, which is clearly «traced» in the future in the works of composers of many countries.

However, the search for an ultra-new musical writing, a pure experiment with sound as such, carried out with only one goal - to create a new sound reality - such searches were absolutely not typical of Prokofiev. He did not seek to discover new principles of musical thinking for the sake of «legislative» establishment of new norms to replace the outdated ones. Prokofiev was inspired by one goal - to create music that would have the ability to influence the listener. He was attracted not by the search for a new 
language, but by a powerful, stunning language that would be the perfect embodiment of the image by expressive means [38, p. 10].

Prokofiev's constant interest in the moral principles of art fills the artist's world of music with contrasts. It is not only the various figurative spheres that contrast: epic, lyrical, comic, etc. Even within a certain ideological and figurative line, numerous contrasting emotional planes intersect. Opposing impulses with varying degrees of intensity permeate all planes of humor, sarcasm, grotesque, buffoonery, eccentricity, caricature (sometimes emotional states of joy and fun are colored with a share of anger, ridicule, irritation). The lyrical line is distinguished by a special versatility of emotional flows. Prokofiev's lyrics is restrained, but extremely sincere story, purity of feelings and great, albeit hidden, heartfelt warmth, bright humanism. For him, this sphere is, first of all, associated with idyllic nostalgic moods, with images of dreams and memories, as "concentration of the ideal" [10, p. 54] - addressed to the rich imagery of the tale, to the imaginary and surreal.

The figurative embodiment of deep and versatile themes in the composer's music is marked by a tremendous force of tension, madness and incessancy (it is no coincidence that the remarque «feroce» appears quite often in Prokofiev). The amplitude of the piano timbres increases greatly. It reflects all those figurative metamorphoses, the dominant content of which is the embodiment of the struggle against evil, cruelty in the human soul, the search for its spiritual powers, the assertion of higher humanity as opposed to baseness, an active, intense assertion.

The sonorics of the composer's piano style is a creative phenomenon. This style absolutely organically combines features of orchestrality and specific piano coloring. The peculiarity of Prokofiev's piano thinking lies in the almost complete identity of the composer's piano and orchestral thinking. Numerous piano transcriptions of his own instrumental works are indicative of the "piano nature" of Prokofiev's orchestral conceptions such an organic arrangement for this instrument. The melody and harmony of the instrumental pieces are fully preserved in the transcriptions, and even the texture of the processed material is almost unalterable: the placement of voices, register and the like are preserved. And, to the contrary, the transcriptions of his own piano pieces for orchestra also retain the characteristics of the composer's piano style. 
The term «percussive» is used to define Prokofiev's pianism This is, first of all, a generalization that emphasizes the dominance of sharp certainty, extreme clarity in the sound of the piano: the dominance of staccato and non legato strokes. And the tough sonority of the composer's works is full of expressive possibilities: from transparently sonorous lively playing to loud accents of heavy chords, which, however, are devoid of rough sound.

Often, for the embodiment of sound images, to which such characteristics as hardness, turning-point, even evil notes can be applied, an exceptionally piercing, clear and sharp intermittent touch - staccatissimo is used (Sarcasms (№ 2), vol. 13, 14). Such a touch requires and, accordingly, allows developing the strength and activity of the fingers, especially their nail phalanges.

A sharp finger staccato or staccatissimo, like any finger staccato, is played very close to the keys. It is performed with a quick, clear, active movement of the finger (finger movement does not exclude the involvement of other parts of the hand in the process of playing; we are talking here about «initiative» in motor activity) without any uncertainty and sluggishness. Before sound production, the playing finger is activated, as if preparing for an instant pluck of a tightly stretched string. At the moment of performing the touch, it slides sharply «towards oneself», «into the palm». This movement can be associated with «cutting» of the sound, «hollowing it out» from the key. During the development of such a technique, that is, exclusively during exercise, before significant activation of the fingers and joints of the hand, you can make a little «swing» of the concentrated rounded finger in order to create a feeling of inertia from its «acceleration», which will help to freely perform strong and sharp sliding. Immediately after sound production, the applied muscle tension must be stopped.

In the works of the composer, especially in their loud episodes, it is appropriate to use motional energy, which is the result of the use of both force and inertia of performing techniques. Probably thanks to such a motor expediency, Prokofiev-pianist, according to the memoirs of the French composer F. Poulenc [30, p. 127], was capable of creating a sonority of extreme power and intensity with only a slight touch to the keys.

Within the framework of staccato, Prokofiev uses the rich expressive possibilities of pianistic pronunciation from a rather short and light staccato (from the keys) to an active, strong strike with the finger from above (push). 
Thus, in the fourth «Fleetingness» (vol. 29-49), the content above and below the staccato sounds of the voice provides for the use of quarters of the finger staccato in the playing, and the quiet and light sound disposes to the barely noticeable touch from the keys. The staccato is performed with a light and short push from the joints of the hand. At the moment of sound production, the fingers do not seem to reach the bottom of the key and then only slightly bounces off it.

In very fast episodes, the finger staccato is pushed from above. This movement reaches its maximum springiness during a loud play of short sounds, accompanied by notes held by the same hand. A good example of a short touch with a similar - "percussive" - use of finger movement is the theme from Toccata d-moll, op. 11 (vol. 77, 78).

In Prokofiev's compositions, the most commonly used staccato touch are techniques that use vibration from the wrist and elbow. In accordance with the tasks of a particular musical context, the technique of performing the wrist and elbow staccato can be adjusted. The features of these types of stab playing are often enriched by the use of finger activity. The determination of the appropriateness of their various options will depend on the interpretation tasks, as well as the conditions that are effective from the point of view of the convenience of performing the touch.

In many episodes of a short ink, especially in a martellate texture, in a bravura playing over the hand (Sarcasms (No. 1), vol. 39, 40), a technique is used, which is characterized by a free, swift lowering of the entire hand from above to the fingerboard - portamento. This type of touch resembles the free fall of the hand from the shoulder. At the same time, while playing the instrument, the actual performance of the «fall» would lead to excessively sharp finger strike and, accordingly, a sharp, poor-quality, rough sound. Therefore, the rapid lowering of the hand on the fingerboard is guided, controlled and ended with a sensitive key pressing.

The domination of staccato and non legato strokes, numerous leaps, sometimes almost continuously follow each other, render extraordinary impulsiveness to the musical language of Prokofiev's piano compositions. The opposite of this movement for the composer is the fast gamma-like passages. In some cases, they are, in fact, an element of the form: they are assigned the role of filling the texture. In some places, such figurations are a virtuoso embodiment of linearity, legato, non-pedalism, which makes a 
transparent texture sparkle. In such a passage figurative writing, the finger technique «perlé» is used - the technique of almost conjunct performance by throwing fingers - «hammers».

The performance of passages, which, in contrast to the ornamental ones, have expressive meaning, needs more sensitivity of the fingertips compared to the «perle» touch for more expressive sound creation. The motor «initiative» in the legato touch, carried out close to the keys, belongs to the fingertips, respectively.

Lyrical episodes sound incomparably simpler and more modest than those of romantics. However, the composer also has a full-sounding cantilena. In the author's performance of the Third Concerto op. 26, the lyrical episode from the middle part of the finale impresses with a real bel canto.

In the cantilena touch, the fingers should be an integral part of all the other arm parts. They must move with the help of a hand, which seems to sense in advance the quality of the sound passed through the performer's consciousness.

The rich emotional and figurative content of Prokofiev's music, the relief character of its themes, flexibility, variety, fruitful diversity of this piano style are characterized by a special colorfulness of the dynamics, which contains many shades of the piano sound palette. In the playing of the composerpianist, who performed mainly his own works, the critics noted the breadth of the amplitude of the dynamic scale - from the subtlest pianissimo to the "terrifying" fortissimo, as well as the clear "carving" of each sound. The performer of his piano compositions should nevertheless remember that antiaesthetic, rough sounds can destroy the highest meaning of the composer's brilliant music. Even in those moments which characterized by the images of a negative order, you need to carefully listen to the performance of loud episodes and to analyze the sound quality in them.

The mastery of subtle dynamic gradations in a strong volume is possible on condition of the free use of the motor resources of the pianistic apparatus, the acquired ability to combine the motor activity necessary in a certain touch with the unloading of the parts of the hand that are not used during the playing.

The records of the composer's playing help to better understand the tasks of performing Prokofiev's dynamic instructions. They indicate the need to strictly follow the letter of these remarques. The more paradoxical, 
in particular, the dynamic instructions in the text are, the more accurately Prokofiev performs them.

In the composer's music, a strict metro-rhythmic organization of texture is dominated. In general, the rhythm of the composer-pianist was often defined as «iron». However, Prokofiev's rhythm did not have the character of a rigid frame, which makes the living process of musical development constrained. The records of the composer's playing convince of the need to use the rhythmic variety of the performance of his compositions. Sometimes, in the artist's interpretation, there are sharp rhythmic shifts that slow down the movement (for example, shortly before the second theme in Toccata), or, conversely, speed it up (before the second theme of the Third Concerto exposition).

One of the distinguishing features of Prokofiev's rhythm as a pianist was also the tendency towards a consistent «acceleration» of the movement, which gave it an overpowering character. Prokofiev also skillfully used the exquisitely patterned tempo rubato. This rhythm will be appropriate, for example, in «Fleetingness» No. 6, 9, 10.

Taking into account the noticeable difference in the creative stages of the development of Prokofiev's piano style, it should be noted that in the rhythm of the late style, the metric ordering gradually increased, the importance of the strong beat grew.

Prokofiev's pedal is one of the phenomena of his original music. In the composer's piano style, bold dryness, percussiveness, and protest against harmonious softening are cultivated. Prokofiev uses the pedal functionally: connects long distances on the fingerboard, holds the bass without overshadowing the whole sound.

But the composer has other fantastic sounds as well. In «Tales of an Old Granny», in the fabulous images of the slow parts of the second and fourth sonatas, an enswathing long pedal is necessary. It creates coloristic wonders.

Thus, the performer of Prokofiev's piano compositions should remember that it is necessary to use a wide range of means of performing intonation in playing, depending on the versatility of the musical tasks of the composer's opuses. The peculiarities of Prokofiev's piano style often require a tremendous energy of «sound cutting» from the pianist. The predominance of staccato and non-legato strokes with very intense dynamics will require an increase in the activity of the fingers, their sharpness and strength, and the speed of attack. 
However, the idea of Prokofiev's playing style as pianism, which is devoid of «overtone», «hard», «staccato», with continuous accents will be far from the truth. Prokofiev himself, if necessary, used a wonderful cantilene legato, «velvet» touch. Therefore, in his style, it would be appropriate to use a diverse, flexible set of means to embody the character of the sound of this music.

\section{Conclusions}

The search for optimal methods for the formation of piano performing technique enhances the importance of studying various instrumental and pedagogical directions, each of which has its own rational grain, experience useful for practical application.

Representatives of the so-called traditional school in matters of pianist training proceeded from the mechanical logic of performing actions, justified by the aesthetic requirements of the times of classicism. The ability to expressive interpretation was considered a manifestation of a musician's talent. This attitude led to the absolutization of the meaning of motor culture, and its formation was reduced to long-term training.

In the second half of the XIX - beginning of the XX centuries, due to the increased attention to the anatomical and physiological aspects of the pianist's activity, the process of formation of playing techniques underwent significant changes. And the representatives of this direction considered it separately from the figurative and semantic and stylistic context of musical compositions.

At the beginning of the twentieth century, the process of the origin of the pianist's motor techniques began to be considered on the basis of a holistic understanding of the tasks of interpretation. The representatives of the new trend transfer the main emphasis in mastering performing skills to the auditory method, that is, to the subconscious embodiment of musical and auditory representations. The «psychotechnical» school of performing skills laid the foundations for a progressive methodology for educating a pianist.

Modern methodological opinion reasonably determines the fundamental directions of the formation of the performer's technique, which is considered in the broadest sense of the concept - as a system of psychomotor skills aimed at full-fledged artistic embodiment of a musical work behind the instrument. Following psychotechnics, the priority task in the development of performing techniques is the creation of vivid sound-like representations 
and the subordination of motor skills to musical and artistic goals. According to the latest studies of psychophysiology and progressive searches of anatomo-physiologists, the process of improving performing techniques should occur not only by the semantic line, but also by the purely motor. Modern pedagogy does not exclude the views of the traditional school about the need to develop the physical qualities of the playing apparatus and, while denying mechanical training at the same time, insists on the constant improvement of the processes of automation of playing movements as a fundamental organization of the performing exercise.

The achievements of piano-pedagogical thought allow us to conclude that the most important component of pianistic training is the technique of sound production. Its factor - the ability to apply in new conditions the previously acquired experience in solving interpretive problems - is no less important. In works devoted to the study of the principles of human motor activity (P. Anokhin, M. Bernshtein, V. Zinchenko, L. Chkhaidze) it is emphasized that it is better to develop such an ability directly during the development of sound production and sound performance techniques, comprehending the content of each component of the performing action. Raising to the level of generalizations in such an understanding in the context of the stylistic characteristics of sound production techniques optimizes the process of the learning subject's search for the similarity between mastered and new performing techniques.

Thus, the artistic and technical aspect of piano performing training should be considered from the position of an integrated approach to the formation of instrumental performing actions. This is, first of all, the interaction of aesthetic, informational, emotional and intellectual and technical components conditioned by musical and stylistic tasks in the process of forming playing techniques. And also the improvement of the technique of sound production from the point of view of performing movements that are convenient and appropriate in various styles of pianism, which will have a positive effect on the ability to achieve virtuoso effects on the tasks of interpreting a musical composition.

In building the educational process in this direction, a formal approach should be avoided. The technique of sound production should be formed as a result of artistic and cognitive, research activity of the musician. Determination of the optimal motor organization in the style of the 
corresponding techniques of sound formation will be appropriate if we refer to the orientation type of actions, as the awareness of those sensations that accompany the convenient performance of the playing techniques.

Only as a result of the creative application of the described basic stylistic features of sound production techniques in the interpretation of piano music by L. Beethoven, F. Chopin, S. Prokofiev, an individual piano performing technique will be formed, aimed at expanding the style scale of the corresponding pianistic arsenal. A more creative approach requires the use of the acquired in this way auditory-motor experience in mastering other styles of piano music. In this regard, an important task of piano pedagogy is the most complete identification of the variety of styles of piano music, related and different characteristics of its phonic images.

\section{References:}

1. Alekseev A.D. (2020). Metodika obucheniya igre na fortepiano [Piano Teaching Methodology]. St. Petersburg: Lan', Planeta muzyki. (in Russian)

2. Alekseev A.D. (1988). Istoriya fortepiannogo iskusstva [History of piano art]. Part 1, 2. Moscow: Muzyka. (in Russian)

3. Anokhin P.K. (1979). Sistemnye mekhanizmy vysshey nervnoy deyatel'nosti. Izbrannye Trudy [Systemic mechanisms of higher nervous activity]. Moscow: Nauka. (in Russian)

4. Aronov A. (1965). Dinamika i artikulyatsiya $v$ fortepiannykh proizvedeniyakh Betkhovena [Dynamics and Articulation in Beethoven\&\#39;s Piano Compositions]. Ob ispolnenii fortepiannoy muzyki Bakha, Betkhovena, Debyussi, Rakhmaninova, Prokof'eva, Shostakovicha [On the performance of piano music by Bach, Beethoven, Debussy, Rachmaninov, Prokofiev, Shostakovich]. Moscow, Leningrad: Muzyka, pp. 32-95.

5. Bardas V. (1928). Psikhologiya tekhniki igry na fortepiano [Psychology of piano playing technique]. Moscow: Muz. sector. (in Russian)

6. Barenboym L.A. (1989). Za polveka: ocherki, stat'i, materialy [For half a century: essays, articles, materials]. Leningrad: Sov. kompozitor. (in Russian)

7. Berkman T.L. (1964). Individual'noe obuchenie muzyke [Individual music training]. Moscow: Prosveshchenie. (in Russian)

8. Bernshteyn N.A. (1997). Biomekhanika i fiziologiya dvizheniy: izbr. psikhol. trudy [Biomechanics and Physiology of Movements: Selected Psychological Works]. Moscow: IPP, Voronezh: MODEK. (in Russian)

9. Bin Van (2010). Metodyka udoskonalennja vykonavsjkoji tekhniky majbutnikh uchyteliv muzyky $v$ procesi fortepiannogho navchannja [Methods of improving the performance technique of future music teachers in the process of piano training: abstract of thesis.] (PhD Thesis), Kyiv: National Pedagogical Dragomanov University. 
10. Chebotarenko O.V. (2003). Zhanrovaya semantika v tvorchestve S. Prokof'eva: na primere fortepiannykh syuitnykh tsiklov [Genre semantics in the compositions of S. Prokofiev: by the example of piano suite cycles.]. Muzychne mystectvo i kuljtura: nauk. visnyk Odesjkoji derzhavnoji muzychnoji akademiji im. A. V. Nezhdanovoji [Musical art and culture: scientific bulletin of Odessa State Music Academy. A.V. Nezhdanova], vol. 4. Odessa: Druk, pp. 48-56.

11. Chen Lu (2015). Metodyka formuvannja vminj muzychno-vykonavsjkoji artykuljaciji majbutnikh uchyteliv muzyky $v$ procesi navchannja ghry na fortepiano [Methods of forming the skills of musical performance articulation of future music teachers in the process of learning to play the piano: abstract of thesis] (PhD Thesis), Kyiv: National Pedagogical Dragomanov University.

12. Chkhaidze L. (1970). Ob upravlenii dvizheniyami cheloveka [On the control of human movements. Moscow: Physical education and sports]. Moscow: Fizkul'tura i sport. (in Russian)

13. Feynberg S.E. (2016). Pianizm kak iskusstvo [Pianism as an art]. St. Petersburg: Lan', Planeta muzyki. (in Russian)

14. Fisher E. (1977). Fortepiannye sonaty Betkhovena: fragmenty [Beethoven's Piano Sonatas: fragments]. Ispolnitel'skoe iskusstvo zarubezhnykh stran [Performing arts of foreign countries], vol. 8. Moscow: Muzyka, pp. 164-198.

15. Gakkel' L.E. (1998). Mirazhi ispolnitel'stva [Mirages of performance]. Music Akademy, no. 3-4, pp. 222-226.

16. Gordeeva N.D., Zinchenko V.P. (1982). Funktsional'naya struktura deystviya [Functional structure of action]. Moscow: MGU. (in Russian)

17. Gofman I. (1961). Fortepiannaya igra. Otvety na voprosy o fortepiannoy igre [Piano Playing. Answers to questions about piano playing]. Moscow: Muzgiz. (in Russian)

18. Gornostaeva V.V. (1973). Mysli o Shopene [Thoughts about Chopin]. Voprosy fortepiannogo ispolnitel'stva [Piano performance issues], vol. 3. Moscow: Muzyka, pp. 178-187.

19. Kashkadamova N.B. (2006). Istorija fortep'jannogho mystectva. XIX storichchja [History of piano art. XIX century]. Ternopil: ASTON. (in Ukrainian)

20. Kashkadamova N.B. (1998). Mystectvo vykonannja muzyky na klavishno-strunnykh instrumentakh [Art of performing music on keyboard and string instruments]. Ternopil: ASTON. (in Ukrainian)

21.Kogan G.M. (1972). Muzykal'noe ispolnitel'stvo i ego problemy [Musical performance and its problems]. Izbrannye stat' $i$ [Selected articles], vol. 2. Moscow: Sov. kompozitor, pp. 5-30.

22. Kuzenkova V.P. (2008). Metodyka navchannja ghry na instrumenti (fortepiano) [Methods of training to play an instrument (piano)]. Vinnytsia: Nova knygha. (in Ukrainian)

23. Lyubomudrova N.A. (2019). Metodika obucheniya igre na fortepiano [Piano Teaching Methodology]. Moscow: Yurayt. (in Russian)

24. Makarov V.L. (1997). Metodika obucheniya igre na fortepiano $v$ podgotovitel'nom otdelenii $i$ nachal'noy shkole [Methods of teaching to play the piano in the preparatory department and primary school]. Kharkov: KhGII. (in Ukrainian) 
25. Malinkovskaya A.V. (2005). Klass osnovnogo muzykal'nogo instrumenta: Iskusstvo fortepiannogo intonirovaniya [Class of the main musical instrument: Art of piano intonation]. Moscow: VLADOS. (in Russian)

26. Milich B.E. (2002). Vospitanie uchenika-pianista [Educating a piano student]. Moscow: Kifara. (in Russian)

27. Mil'shteyn Ya.I. (1987). Ocherki o Shopene [Essays about Chopin]. Moscow: Muzyka. (in Russian)

28. Mozghaljova N.Gh. (2012). Teorija i metodyka instrumentaljno-vykonavsjkoji pidghotovky majbutnikh uchyteliv muzyky [Theory and methods of instrumental and performance training of future music teachers: abstract of thesis] $(\mathrm{PhD}$ Thesis), Kyiv: National Pedagogical Dragomanov University.

29. Moskalenko V.Gh. (1999). Pro specyfiku muzychnoji interpretaciji [On the specifics of musical interpretation]. Kyjivsjke muzykoznavstvo. Problemy muzychnoji interpretaciji [Kyiv musicology. Problems of musical interpretation], vol. 2. Kyiv: KDVMU imeni R.M. Ghlijera, pp. 4-44.

30. Nest'eva M. (1990). Prokof'ev-pianist [Prokofiev - the pianist]. Sergey Sergeevich Prokof'ev [Sergei Sergeyevich Prokofiev]. Moscow: Muzyka, pp. 124-129.

31.Petrushin V.I. (1997). Muzykal'naya psikhologiya [Musical Psychology]. Moscow: VLADOS. (in Russian)

32. Sajik Gh.F. (2000). Formuvannja vykonavsjkoji majsternosti studentiv na osnovi aktyvizaciji emocijno-estetychnogho perezhyvannja muzyky [Formation of performing skills of students on the basis of activation of emotional and aesthetic experience of music: abstract of thesis] (PhD Thesis), Kyiv: Kyiv National University of Culture and Arts.

33. Sakhaltueva O.E., Nazaykinskiy E.V. (1970). O vzaimosvyazi vyrazitel'nykh sredstv $\mathrm{v}$ muzykal'nom ispolnenii [On the relationship of expressive means in musical performance]. Muzykal'noe iskusstvo i nauka [Musical art and science]. Moscow: Muzyka, pp. 59-94.

34. Savshinskiy S.I. (2020). Rabota pianista nad muzykal'nym proizvedeniem [The pianist's work on a musical composition]. St. Petersburg: Lan', Planeta muzyki. (in Russian)

35. Shul'pyakov O.F. (1986). Muzykal'no-ispolnitel'skaya tekhnika i khudozhestvennyy obraz [Musical and performance technique and artistic image]. Leningrad: Muzyka. (in Russian)

36. Synycyn V.M. (1981). Artykuljacija jak predmet vyvchennja [Articulation as a subject of study]. Pytannja fortepiannoji pedaghoghiky ta vykonavstva [Issues of piano pedagogy and performance: collection of articles]. Kyiv: Muzychna Ukrajina, pp. 62-69.

37. Sjuje Van (2017). Formuvannja zvukoobraznykh ujavlenj molodshykh shkoljariv u procesi fortepiannogho navchannja [Formation of sound-image representations of junior schoolchildren in the process of piano teaching] (PhD Thesis), Kyiv: National Pedagogical Dragomanov University.

38. Tarakanov M. (1972). Prokof'ev i nekotorye voprosy sovremennogo muzykal'nogo yazyka [Prokofiev and some questions of the modern musical 
language]. S.S. Prokof'ev: stat'i $i$ issledovaniya [S.S. Prokofiev: articles and research]. Moscow: Muzyka, pp. 7-36.

39. Tarchynsjka Ju., Boruta K. (2018). Metodychni zasady u pedaghoghichnij spadshhyni koryfejiv ukrajinsjkoji fortepiannoji shkoly (na prykladi kyjivsjkoji ta ljvivsjkoji pianistyky) [Methodological foundations in the pedagogical heritage of the leading figures of the Ukrainian piano school (by the example of Kyiv and Lviv pianists)]. Scientific Bulletin of the Lesia Ukrainka Eastern European National University. Series: Pedagogical Sciences, vol. 382, no. 9, pp. 17-24.

40. Tarchynsjka Ju.Gh. (2012). Formuvannja racionaljnykh pryjomiv ghry na fortepiano [Formation of rational techniques for playing the piano]. Rivne: Volynsjki obereghy. (in Ukrainian)

41. Terent'eva N.A. (1999). Karl Cherni i ego etyudy [Carl Czerny and his concert etudes]. St. Petersburg: Kompozitor. (in Russian)

42. Timakin E.M. (2019). Vospitanie pianista. Metodicheskoe posobie [Pianist education. Methodical manual]. Moscow: Muzyka. (in Russian)

43. Tsypin G.M. (2001). Muzykal'no-ispolnitel'skoe iskusstvo [Musical and performing arts]. St. Petersburg: Aleteyya. (in Russian)

44. Tsypin G.M. (1984). Obuchenie igre na fortepiano [Learning to play the piano]. Moscow: Prosveshchenie. (in Russian)

45.Zinchenko V.P. (2018). Psikhologiya predmetnogo deystviya [Psychology of objective action]. St. Petersburg: TsGI Print. (in Russian) 